This is the accepted manuscript of the article, which has been published in Cultural and Social History. https://doi.org/10.1080/14780038.2019.1658838

\title{
Children's Emotional Formations in Britain, Canada, Australia and New Zealand, around the First World War.
}

Wartime emotional and moral conditioning of children and youth, and their cultivation as future citizens, began before the First World War and continued long after it. Going along with the idea that it is the "'feel" of a thing is what matters here', I will sketch out some of the many interactions with material print culture, an important part of children's material cultural heritage during the war and immediately after it. Focusing on material that is largely overtly didactic, I measure its reception among children in order to try to understand children's emotional formations and the emotional frontiers they traversed in their daily lives. ${ }^{1}$ The argument here is that a childhood sense of belonging - to nation, to empire was predicated on children's formulations of their role in the war and their identification with the war 'effort', and that these formulations were deeply entangled with reading and handling certain types of print. The article therefore begins by introducing the concepts of formations and frontiers, connecting them to material culture and cultural heritage. This is subsequently exemplified by the remarkably enduring image, 'Which Path Will You Take?' as it appeared in different places at different times, which emphasizes the kind of moral narrative children had to negotiate. This is followed by an examination of styles of training for the purpose of belonging, and the strong tendency for pedagogical material to focus on types of 'service'. A sense of the reception of this kind of material is gained through children's responses to it in the Jephcott Essays, written for a competition in Victoria, Australia, which demonstrate the effects of emotional formation and active 
negotiation of emotional frontiers. Children's voices here, channeling the cultural heritage to which they had been subjected, range from certainty to equivocation.

\section{Formations and Frontiers}

Emotional formations are produced and reproduced by doing, learning and articulating, in order to produce specific habits of feeling in the self or in others. In this way, children learn what is expected of them - what they should or should not feel or what they should or should not display - by doing, and by learning what works and what does not within the various emotional communities in which they operate. Individuals or groups might find themselves between competing emotional expectations, not knowing how to feel or how to express feelings: this is an emotional frontier. For children, the emotional frontier is complex and constantly shifting ground. A child's emotional development is influenced by any number of agents and experiences, in a constant process of negotiation. This, of course, includes the child's own capacity to shape her development in concert with or in opposition to these forces. In the simplest of cases, we might identify the child at the emotional frontier between home and school, or between school and street. Each location and its accompanying personnel have their own prescriptions and expectations. ${ }^{2}$ Looking at cultural heritage and material culture for children around the First World War demonstrates how such emotional work functioned in children's everyday lives.

The idea of the child as future citizen was prevalent in the context of the First World War in Britain, Australia, New Zealand and Canada. This future-oriented work toward citizenship, whether by children or for children, is not indicative of specific attempts 
strategically to instrumentalise children as capital or as resources, but is rather evidence of a moral concern about who will physically embody national and imperial polities. At an individual level, children were asked 'which path will you take?' At national and imperial levels, this was the same operative question. Whether the future adult was to be a citizen or a subject, the concern was that they would be moral, emotionally adjusted in the prescribed way. Hope, fear and despair in educational and welfare strategies, policies and ideals were mobilized to shape childhood purpose, morality and identity. It is clear that these threads were transnationally intertwined. This focus also highlights the tensions of Imperial belonging, which refers to how children in these four countries were taught to embrace notions of national identity and patriotism while at the same time acknowledging a sense of belonging to a larger and more powerful imperial body. ${ }^{3}$ This sense of belonging was to be cultivated through the training of the emotions, using strategies developed before the First World War in relation to the formation of 'character' as an embodied sense of morality. The question of what to hope for, and indeed what to fear, is likely to have changed in each national context as notions of national belonging, citizenship, and future security were tested in the crucible of a long and taxing war and its terrible reckoning.

In the nineteenth and twentieth centuries, however, worthiness for citizenship was greatly dependent on gender and race, complicating the idea of the child as future citizen. In each of the Dominions studied here, the debates about nascent nationhood and citizenship were inflected by the particularities of colonial relations with indigenous populations, whose alignments with settler authorities and the British crown were often fraught and often disastrous for them. In Canada, the Francophone population, who largely opposed the war and conscription, offer another dimension of difficulty to further 
complicate narratives of national emergence. Material culture for children around the war reflects this context. The target audience was mostly assumed to be white and of British heritage, or at least wanting to emulate or embrace that heritage. ${ }^{4}$ This is reinforced by the fact that much of the material for children in the Dominions was produced in Britain. Even local publishers reproduced British material, though sometimes adapting it with the local market in mind. There was also an ever-increasing amount of local content in Canadian, Australian and New Zealand material for children.

Young people in the British Empire were exposed to prodigious amounts of tangible material related to their experience of the First World War, from before the actual start, to after Armistice. Much of it was ephemeral in nature, but by no means all of it. There remains a rich source base of material through which better to understand children's emotional formations. Materiality can be extended to include the bodies of other people, meaning we should think about the impact of other bodies - children's, teachers', parents' and other adults' physical presences - on children's ideas and experiences about the war. Young people traversed various emotional frontiers during the war and tried to match up their emotional formations to what was required of them in different social and cultural settings. Several historians have pointed to the myriad objects that children encountered and engaged with in the war, from books, to games, to postcards, to uniforms and costumes, to personal letters. ${ }^{5}$ As objects in that particularly charged cultural context, they would have had significant and weighty emotional value. Moreover, a basic, but essential point is that children (even those not in war zones themselves) would have been confronted by the war on a daily basis, in the form of uniformed adults (and sometimes children), the war wounded who had returned home, the loss of loved ones, and the influence of peers in 
school and in the wider world who exerted pressure on children to conform. These bodies substantially contributed to children's emotional formation in the First World War, and worked together (or sometimes against) objects, texts and other material traces of the war.

In Children, Childhood and Cultural Heritage, Kate Darian-Smith and Carla Pascoe take a broad view of children's and childhood cultural heritage, taking into account 'material culture', 'intangible heritage' and 'spatial heritage'. ${ }^{6}$ While the focus here is primarily on printed sources, the question of children's emotional education in the First World War requires an examination of all of these components of cultural heritage. Furthermore, some recent work has tried to tie the study of material culture more closely with the history of emotions. According to the editors of a recent volume, 'material culture itself may be productively understood as a 'form' of emotional expression, capable of embodying the emotions of individuals and groups' ${ }^{7}$ If feelings are embodied, as many historians of emotion now argue, they can be 'experienced physically as a participant in the material work' ${ }^{8}$ Children's material culture assisted in this work.

\section{Which Path Will You Take?}

\section{Image 1: Which Path Will You Take?, Seed Time and Harvest, March (1908): 17, author's collection.}

As a dual moral narrative in pictorial form, 'Which Path Will You Take?' was a lithographic illustration comparing 5 stages of a boy's life from childhood to adulthood. It demonstrates the importance for young boys of taking the right path while they were still 
young enough to be shaped. It can be seen as early as the March 1908 issue of the Religious Tract Society's publication for its workers, Seed Time and Harvest, used by teachers in elementary schools, Sunday Schools, mission halls and boys' clubs in Britain before the war. It is an important piece of cultural heritage that exemplifies the argument that major shifts in childhood emotional formations could nonetheless utilize informal educational material that was itself unchanging. This particular image remained exactly the same and stayed in popular use, despite major social, political and national upheavals. The object's inertia belies the transformation of its import and significance, as it appeared in different places and at different times.

The moral path visualises the boy's transition through the life stages necessary to take up his rightful place as citizen and head of family. He is attentive at school, practices fair play at cricket, learns a respectable trade, provides for a comfortable home, takes pride in his family, and retires to a quiet life of dignity and refinement. The other path demonstrates what could go wrong if boys were not properly guided: the young boy falls asleep at his lessons; gets into mischief in the street, gambles on horses, neglects his family in favour of drink, and ends up a beggar on the street. According to this brand of emotional formation, the building of moral character, with a commitment to work and family, allowed boys of merit to reach full membership in society as citizens and fathers; conversely, intemperance led to poverty and depravity. Future happiness, boys were taught, was far more important than immediate, false gratification. ${ }^{9}$ This was the sort of emotional formation that First-World-War era children brought into their view of the war and their own roles in wartime. 
Insofar as institutional settings for informal education were proliferating in the last decades of the nineteenth century, this image as pedagogical tool was itself already an innovation that encapsulated the Religious Tract Society's own cultural heritage of moral education, emphasising long-standing concerns about family, learning and delayed gratification. It packaged these ideals in a new material form that was in keeping with the kinds of imagery that were rapidly proliferating in the expanding juvenile periodical press. But if the image itself is - in pictorial form - emblematic of long-standing concerns, it would come to have a life of its own over the decades, being received and 'read' according to the shifting national and imperial political implications of childhood path choosing.

In 1908, in an upper middle-class (or even an aspirational working-class) British context, what lay at the end of the correct path was implicitly inclusive of citizenship, encapsulated in the activities of work and duty to family. But what did it mean to 'read' such an image in the period of war, or afterwards, in context of incipient nationalism and where, amid a general crisis over the present and future state of civilization, the significance of what and who should influence youthful 'paths' had become more acute? It is important to point out that this image appeared in vastly different contexts throughout the British Empire, in several languages, before and after the war. It seemed to be an effective tool for the influential Director of Education for the Australian state of Victoria, Frank Tate and his staff, since it was reproduced several times during and after the First World War in the School Paper, the compulsory reader for all school children in that state. ${ }^{10}$ Readers might view duty in such an image in two ways in the context of war: by joining up or by staying home. Even at the start of the war, the effect of cultural heritage was being disrupted by events. The Australian examples in the School Paper represented a shift in national, 
pedagogical and class contexts for the image, moving from an informal context to a formal one in school, and from a religious context to a somewhat secular one. There could be no doubt about which 'path' such a boy was supposed to take, but that 'path' was by no means the same in the imagination of the boys who 'read' such an image as it had been for British boys in 1908.

Though a proliferation of material for children developed over the course of the war and after, many of the ideas influencing this material had pre-war origins. I have described such material - juvenile literature, the periodical press, and the efforts associated with youth movements and organizations - as the means of 'informally educating' a generation of children, in emotional disposition, moral bearing, and that nebulous quality,

'character'. ${ }^{11}$ The question of 'Which Path Will You Take?', though it seemingly resonated with children from the early 1900s to at least the late 1920s, would have had different significance to children in pre-war Britain and children during the war in Australia, Canada or New Zealand. This leads to the key question: to what extent did the cultural heritage of boys' character, moral duty and emotional education continue to influence children as they grew up during the war?

\section{Tensions of Belonging}

Pre-war and early-war material did not necessarily predict children's responses to the war, but it absolutely framed those responses, and the effort to continue to hone this cultural heritage continued throughout the war and immediately after it. While major changes in welfare and education were difficult to institute under war conditions, the war itself seemed to demand reform, and much effort was spent in popular culture, schools, youth groups and 
homes to try to maintain, influence and direct children's spirits. Children's experiences of war were in large part shaped by these efforts. Of course the experiences of children in Britain, confronted with the terrifying material reality of war, were different from the ones experienced by most children in the Dominions. However, the psychological trauma of losing a loved one or of the possibility of losing the war itself, were shared experiences, much discussed in the press in the Dominions and in Britain. There was a great exchange of information about children and childhood and what to do about them in these countries. Children could access some of this information themselves in newspapers and popular family journals. There were also many stories designed to create an emotional link for children from the Dominions to what was going on in Europe. This helped them to cross a wartime emotional frontier, or conversely, put that frontier into stark relief.

If we take a big picture view, encompassing political and pedagogical visions, from the point of the view of the Metropole, we can identify a loose consensus on the war as it was being fought, formed around certain themes for children: Britain (and Dominions) would surely win the war. Peace would follow, and the nature of that peace would be constructed, or at least heavily influenced by the British. The question was the extent to which British notions of citizenry would be built into educational plans across the Empire, and what precisely was at stake in future projections of what citizenry should mean and how it should feel. Serious divergences were evident in the details, especially once Dominion political voices were factored in. All of the Dominions under consideration here have their own (now highly contested) stories of nationalist origins oriented around their contribution to the First World War. ${ }^{12}$ In many cases, repetition of such stories overlook the divergence or plurality of views within each polity, as well as underplaying the 
complexity of expressions of hope for a new national identity, distinct from Imperial belonging or subjecthood. Still, children's own impressions of who they were and who they wanted to be seem to be the foundational documents or expressions of these new national identities. Hopes for a better future as Canadians or Australians or New Zealanders were shaped in the classroom, in youth groups and in other organizations in the absence, or perhaps because of the absence, of military personnel. This in turn places an enormous emphasis on the kinds of materials used in the classroom environment, and to the cultural heritage that they represent. Even a cursory analysis of such educational material, from all of these places, points to complex identity formations and innovations and the vagaries of the perceived instrumentality and malleability of children, and their special significance in being the subjects and objects of hope in this context.

The war created a revised framework for understanding morality, emotions and education for children and youth, both in the national and international context, amid the ongoing tensions of imperial belonging. As early as 1915, it was considered to be the 'spiritual forces of the nation, the forces that will be taxed to the uttermost when the work of recovery from the war begins' that were to be guarded. According to the Bishop of Oxford, writing for the Workers' Educational Association, the most important of these spiritual forces was children's education, by 'awakening and training the capacities of the child'. 13 Educationalists, psychologists, youth workers, politicians, eugenicists, temperance advocates, soldiers and parents all worried about 'saving the future' while the war was still raging. After the war, efforts to train a new generation began in earnest. As Caleb Saleeby, eugenicist, physician and writer/journalist for children and adults, wrote during the war 'The real issues as to who shall rule and lead will be determined by the 
quality of the adult young citizens of 25 years hence, whatever military operations may occur to-day. ${ }^{, 14}$ While there was hope that children could be formed into good citizens, the question of what, or who, they would serve or lead remained open.

In the British metropole and in the Dominions, there was much attention to what kind of training this should be, with some significant points of consensus. Moral instruction was found to be paramount, since it would 'move young souls to admiration, hope, and love. ${ }^{15}$ In Britain, the Final Report of the Departmental Committee on Juvenile Education in Relation to Employment referred to the great 'hopes of education' after the war. ${ }^{16}$ In Canada, as a Winnipeg journal for teachers and students pointed out in 1915, the onus during this 'critical time in the development of the moral and ethical life of our people' lay with the public schools. ${ }^{17}$ In Ontario, for example, much classroom material was specifically adapted to address the war. This includes official textbooks and standardized exam questions, lists of recommended reading, and more informal material shown and discussed in the classroom. In some other places, New Zealand being a prime example, military training had been compulsory for almost all schoolboys even before the war began. Yet uniformed militarism took on increased importance in many places and many schools. In Vancouver, the capital of British Columbia, cadet corps flourished and photographs of these uniformed boys and of cadet corps bands were proudly published. ${ }^{18}$

\section{$\underline{\text { Training and Service }}$}

Emotional training was, however, certainly not only about schooling. As Kate DarianSmith and Carla Pascoe argue, 'the objects that pervade a child's life are often made, purchased or gifted by adults, they offer insight into such adult aspirations for children. ${ }^{, 19}$ 
But a focus on children's emotional formation around these adult-directed objects, in addition to looking at material produced or chosen by children, wherever possible, also provides us with a more complete picture of children themselves.

Intertwined with the focus on the perceived need for educational and child welfare reform by professionals and politicians was a focus on children themselves and their emotional coping during the war. Children across the Empire were inundated with media related to the war, both in school and outside. In addition to songs, pictures and other media, there was much illustrated reading matter in a patriotic spirit, explaining the reasons for war and detailing military exploits. In Britain, much of this can be classified as patriotic or even jingoistic propaganda in the form of children's reading material, about the superiority of Britain and Empire and the vilification of German leaders, and indeed, one finds plenty of similar material in the Dominions.

Some important examples include The Children's Story of the War by Sir Edward Parrott, published in 10 volumes from 1915, to the volume on 'victory!' in 1919, and of course, serial stories ran in The Boy's Own and The Girl's Own papers, as well as in the Empire Annual and many others. Many books written for children and youth and read inside and outside classroom settings provide material evidence of the sort of emotional formation children were receiving. A Child's History of Anzac (1916) by the Australian journalist and author E.C. Buley, published in London but directed primarily at the Antipodean-child market, presented interesting photographs of guns and battles. Although it contained a chapter on 'The Seven Plagues of Anzac' and discussed obstacles, diseases, injuries and death, and the ultimate defeat that would have such devastating effects for the soldiers, it focused on the heroes as well as geography, machinery and strategy. It was akin 
to a story in the Boy's Own only in real life. It is difficult to assess the consequences to those children directly affected by Gallipoli and the war in general in reading such a text. There must have been several layers to their reading and understanding in being entertained by a rip-roaring story, in being awed, impressed or horrified by the actions of the men they knew, in trying to rehabilitate these momentous events which were clearly outside of their everyday understanding to find the heroic in the terrifying. This was a vast emotional frontier that was probably unimaginable in peacetime, but quite necessary to cross during the course of the war.

\section{Image 2: cover of $A$ Child's History of Anzac (1916), author's collection.}

Specifically for the classroom, educationalists and writers designed periodicals, books and pamphlets about the war, children's emotional formation and the important roles children had to play. For historians, this is more than text-based evidence. It is the material cultural heritage of the war: both evidence of the prevailing context of imperial militarism of the pre-war years, and of the shifting realities of a wartime present. These volumes were passed around, dog-eared and scribbled on. The placement of content, stories, poems, factual information and pictures all added to the overall emotional formation of children and youth. The New Zealand School Journal was mandatory reading in all schools in New Zealand. Its uniform jingoistic message reached every child and teacher, and no doubt parents also frequently read it. Its pedagogical approach was consistent, such that familiarity with the medium would have aroused in its would-be reader an anticipation of its contents, however those contents might have been received on an individual level. It is 
a clear example of 'top-down' emotional formation, focusing on battles, gallant soldiers, strategies and king and empire. In contrast, Victoria Australia's School Paper provided students with profuse information and opinion on the war. Especially as the war progressed, it presented a more balanced view of the hardship and devastation of war, as well as stories and lessons for children about their diverse roles in the war, and the lessons they should learn from them. Moral lessons, like being temperate, kind and truthful, played a large part, as did charity and helpfulness. What both media have in common is a more or less implicit awareness that childhood emotional formation was up for grabs in a fraught moment of emergent identities and political fracture.

Unsurprisingly, therefore, this is only part of the stories of Australian, Canadian and New Zealand incipient nationalism, or of British imperialism. The notion of service was widespread and came with various levels of expectation about the capacity of children to learn to put nation, community and/or family before self. Tate, the Director of Education in Victoria, explained that the war provided a useful educational opportunity for school children to teach them that 'good citizenship is made manifest by willingness to serve the community' [in order to instill patriotism], and that this 'world-calamity was thus the teacher's opportunity' with schools as 'laboratories of good citizenship.' As he explained, 'The Outbreak of the war emphasized the truth that Teachers realized that this evil thing, the war, might be a potent influence for good in the lives of their pupils, if only they could be taught the lessons of unselfishness and sacrifice'. ${ }^{20}$ Furthermore, as he saw it, 'To allow children to stand idly by and view as indifferent spectators the awful sufferings of to-day would be to commit a grave wrong against them'. But this emotional and citizenship training was actually future oriented. Tate questioned how 'our broken men' would fare in 
20 years. 'Shall we see exemplified "unregarded age in corners thrown", with only the cold comfort of a Government pension?', he asked, 'Or will our gallant boys be taken into the hearts and lives of a people who will remember with pride and with gratitude what they did on Gallipoli, in France and in Palestine?' In his influential opinion, 'The answer all true men desire is being shaped in the schools to-day'. ${ }^{21}$

School children read and discussed the many ways they could be of service. In November 1916, in an article entitled 'The Broken Soldier: Plans to Help Him', Grades 3 and 4 in Victoria were described as selling flowers, visiting Caulfield Military Hospital and locations where wounded soldiers were and giving the patients gifts like hand-knitted socks. The article goes on to reproduce a report from Jack Lockhart from Glen Creek, near Bonnie Doon:

All the children in his school have joined the Young Workers Guild. They have sown two plots of vegetables for the Fund. Everybody is doing raffia work; and the serviette rings sell at two shillings a dozen. Then the children make baskets also, and collect horseshoes and waste paper, and rabbit skins and stray tufts of wool. Aleck Lockhart has sold his pet lamb and given the money to the Fund. ${ }^{22}$

Similar material from Canada and New Zealand demonstrates that many school children were keen to demonstrate that they were of service in the war effort.

Service could, however, be viewed in different ways. Beyond formal pedagogical material, there was an important counter movement to train children in ideals of peace and in hope, during the war and immediately after it, and directly addressing the cultural heritage of youth that had been brought into the war. There were strongly contrasting 
currents from place to place, such as the mass opposition to conscription in Australia. ${ }^{23}$ One British commentator praised education books with a focus on universal peace as training 'the young citizen to escape the prejudices concerning patriotism and war they have inherited; and fitting them to take their place amongst the peacemakers of the war' ${ }^{24}$

In 1919, F.J. Gould, the prolific London writer on education, published a book for young readers called Towards a World at Peace, promoting the League of Nations and 'universal peace', and exclaiming: 'Noble flower of world-peace! We may never see it; but other eyes are sure to see it; and it is good to wait for it, and hope for it, and labour for it. ${ }^{25}$ The rise of national interests among the Dominions was both supported by and ran in contrast to the internationalism of The League of Nations, which was promoted by peace educationalists immediately after the war for children's education in books, songs and even pageant plays. One pageant play for children, The Peacemaker, published in England in 1922 focused on the fear associated with war, and even the fear to hope, contrasted with the hope that peace and the League of Nations would bring. ${ }^{26}$

Certain groups in all countries had vocalized this message of peace, albeit in a muted way, throughout the war. In Australia, for example, Commonweal, run by wellknown Melbourne pacifist, Rev. Charles Strong, contained a regular children's page. From 1915, the journal also included an insert called 'Peacewards', which often had direct appeals to children. ${ }^{27}$ Most educational messages (formal and informal) for children during and after the war, however, toned down any doubt, and provided them with a coherent, straightforward message of sacrifice, victory and patriotism, whether to the Empire, and/or to their own nations. This strand of cultural heritage was focused on the important part that children had to play in the war, especially as beacons of hope for all in wartime; the 
valuable lessons they could learn through these activities and emotional labour, and most importantly, to embody the idea that they were the hope for the future of the empire and/or the nation.

\section{$\underline{\text { The Jephcott Essays }}$}

The Jephcott essays, which were written by children in Victoria, Australia, who were aged around 12-14 years old, are a prime example of how children's emotional formations took place through the material cultural heritage around the war. The theme of their essays was 'Patriotism in Peace and War', written for an essay contest inspired by George Jephcott, nationalist, councillor for the rural shire of Upper Murray and author of The Great Conscription Crisis, who donated $£ 20$ annually for 3 years to establish the essay competition as a means to combat the 'strong tendency in a certain section of thought, of teaching to condemn Patriotism, to refer to it as an evil. Those prophets who teach this are false ones', he said, noting that 'National Patriotism need not be narrow or cruel, it should NOT be. It should and does when rightly realised improve and strengthen character'. The essays demonstrate that most of the child writers agreed with Jephcott's agenda and his positive view of 'national patriotism'.

The school children's essays are especially valuable in showing how children internalized these messages, fashioning themselves as patriotic beacons of hope, or at least writing what they thought their teachers would want to hear and what would win them prizes. Reading for intention is tricky, but at least sources like these give us the child's voice in the process of collective emotional formation. Interestingly, these sources echo many of the messages found in the Victorian School Paper, which these students would 
have had to read (and even memorize) regularly in the classroom, but they still carry an individual flavour.

A boy, aged 13 and 10 months, writes of the need to 'keep on working... with a free heart having no fear of our liberty being taken from us', while a prize-winning essay weighed in on the Australian conscription debate, arguing that the Australian army consisted of patriots because they had not been forced to fight through conscription. ${ }^{28}$ 'If a country consisted of all patriots', the 13-year-old wrote, 'there would be no need for conscription.' 29

Many students observed that, 'Patriots don't smoke or drink', which they would have been taught in the School Paper, or if they had attended the Band of Hope, or numerous similar organisations. These lessons were tied to general advice on hygiene and character training. A 12-year-old boy wrote that: 'We should protect harmless birds and keep ourselves tidy'. ${ }^{30}$ Concrete examples of how children could be patriotic were enumerated, among them knitting, gardening, collecting leeches, raising money for school patriotic funds, and visiting soldiers. They could also 'show their patriotism by denying themselves picture shows, sweats [sweets], and luxuries' ${ }^{31}$

Children's own special contributions as patriots, as distinct, from adults', were frequently reiterated, as in this 13-year-old girl's essay:

We children can be patriots by doing our work, both at home and at school, honestly and well. When we do this we are being good citizens, and so we are helping our country, and at the same time we are learning to be good men and women, so that we may help. ${ }^{32}$ 
In this way, many students tied the emotional training they were receiving during the war in school with their future roles as adult citizens. Another 13-year-old writes: 'As children we can show our patriotism by obeying our teachers and keeping the rules of the school, and this will teach us to keep the laws of our country when we grow up ${ }^{33}$ Here obedience training is intimately tied to good citizenship, as were numerous special tasks that children assigned themselves.

'Thus', one 13-year-old girl argued, 'if we do our tasks honestly as children, will we not grow up into good citizens, and so make this world happier, brighter, and more healthy than it was? If we do this, and it is only our duty to do it, then we shall be patriots'. ${ }^{34}$ Others mention their education could lead them to even more helpful roles as future doctors or nurses, as one girl writes, 'to help in a still better and closer way'. ${ }^{35}$

In these children's essays, the gallant efforts of the soldiers are stressed, as are their own important roles in the war, and their even more important future roles in peacetime. These peacetime roles include being temperate, peace-loving and hard-working, and supporting the Empire, and/or their country. The children often repeated the need to work for their country (Australia), or more local units like their district or their community. Some children tied this in with duty to the Empire, or a brotherhood of nations under the Union Jack. One student remarked that a patriotic good citizen in peacetime is an empire builder. ${ }^{36}$ Most students emphasized the need for peace and the destructiveness of war. A prize-winning essay, written by a 12-year-old girl, echoes the common refrain:

Yet, even though peace has been once again restored, in our land, we must still keep on helping, for this war has cost our empire dear, and we do not want to leave off helping yet, but wish to still maintain our name of 
patriots, for it is not only in wartime that we must be patriots, but in peacetime also. We can help our country in such ways as to prevent war, or try to prevent it, for fighting does not do our empire any good. ${ }^{37}$

Patriotism, at the end of the war, meant working to maintain peace, but the emotional frontier here is thrown into relief by the tension between past efforts to support war and current ones to ensure peace. The proper object of patriotism - an emotional object - was shifting, even if the practical activities associated with it were clear.

Many children held the view that patriotism was not just a wartime slogan, but a lifelong commitment and self-sacrifice. One girl echoed a popular sentiment, noting that: ...in peacetime [people] seem to think of themselves as individuals and forget their part in the special whole. Let us hope that this war will have inculcated in the citizens of this country a patriotism of patient work for Australia, as well as noble life sacrifice, the realization of the nobility of the ordinary duties of every-day life. ${ }^{38}$

Here, perhaps, there is more consistency, of an identity of 'special whole' with 'Australia', and there is also a clear claim of citizenship tied to the nation that negotiates past, present and future. It suggests a frontier negotiated resulting in a particular political viewpoint, however implicitly or unconsciously stated.

Others were critical of showy wartime patriotism, and contrasted this with 'true' patriotism: 'Some people think they are winning the war if they go about waving flags; but they are not. They would do more good if they were working for the soldiers. ${ }^{39}$ On the whole, these children had well defined views on patriotism, war and peace, and the distinct 
roles they had to play to ensure a hopeful future, but collectively they show a remarkable diversity of constructions of patriotism. To love the greater polity was a given. What that greater polity was, and how to love it, were negotiable or uncertain.

Judging by the children's essays examined here - admittedly a rare repository of children's voices - the majority had appropriated the dominant sentiments learned in informal and emotional education, replete with its internal tensions. It was no longer completely clear if community, nation and empire were all part of the same endeavour, or if they in fact carried distinct aspirational narratives. It is impossible to tell, of course, if these children merely parroted back the messages designed for them, or if they truly internalised them, but perhaps the distinction, or the question of authenticity, is a false one. As a collective emotional practice, the task of writing about patriotism and hope for the future was formative emotional work.

Children throughout the British Empire were encouraged by schools, organizations and communities to participate in the First World War as future citizens. Children responded to these appeals in multiple and creative ways. They raised money by holding bazaars and teas, selling handmade goods and home-cooked food. They collected for the Red Cross, the Belgian and Serbian Relief funds and many other specifics causes during the course of the war. They visited soldiers in hospital and brought them presents. They collected leeches, scraps and metal. Across the Empire, from Indian Head in Saskatchewan, Canada to Melbourne in Victoria, Australia, children wrote essays, drew pictures, and composed letters for education ministers, youth leaders and other adults detailing their thoughts and efforts. Through these actions and everyday endeavours, children contributed to the enormous emotional effort of the war. The material traces of these contributions, as 
well as the much larger remainders of efforts by adults to influence children's emotional formation and conditioning, are all evidence of children's cultural heritage around the First World War. This heritage began before the war started, and was continually fashioned and refashioned as the war raged on, with similarities throughout the British Empire, but also nuanced by particular events and experiences affecting particular nations or regions.

\section{Conclusion}

As Downes, Holloway and Randles point out, 'An object which does not materially change may undergo drastic changes to its emotional value in response to shifting emotional contexts' ${ }^{40}$ The cultural heritage that children brought with them into the First World War and the media content directed toward them throughout the course of the war remained relatively constant, but the impact on children of this material changed over time. Interaction with, and the significance of, this material were also transformed, but perhaps not in linear or in entirely predictable ways. Children's responses to the war at the end of it go some way towards an understanding of the changing emotional value of those objects. In turn, these objects, combined with their changing emotional contexts, before, during, and after the war, affected children's education and emotional formations. In what ways this occurred depended on individual experience, even if emotional enculturation was intended to be collective, determined by location, age, race and myriad other factors: the emotional frontiers the child had to cross.

\section{Acknowledgements}


The author wishes to thank Kate Darian-Smith and Ana Carden-Coyne and the anonymous reviewers for their helpful comments and suggestions. She is grateful to the Social Science and Humanities Research Council of Canada for its generous Insight Development Grant in support of this project.

\section{Disclosure statement}

No potential conflict of interest was reported by the author.

\section{Notes on contributor}

Stephanie Olsen, Ph.D, FRHistS, is an historian of childhood and youth, education, and the emotions, with a particular focus on the British Empire in the nineteenth and twentieth centuries. She is a Senior Researcher at the Centre of Excellence in the History of Experiences (University of Tampere), having previously held positions at the Max Planck Institute for Human Development, Center for the History of Emotions (Berlin) and the Minda de Gunzburg Center for European Studies at Harvard University.

She is the author/co-author of two monographs, Juvenile Nation: Youth, Emotions and the Making of the Modern British Citizen (Bloomsbury, 2014) and Learning How to Feel: Children's Literature and the History of Emotional Socialization, c. 1870-1970 (Oxford University Press, 2014), and the editor of the collection, Childhood, Youth and Emotions in Modern History: National, Colonial and Global Perspectives (Palgrave, 2015). Her new research focuses on children's education and the cultivation of hope in the First World War. It is supported by a Social Science and Humanities Council of Canada Insight Development Grant. 
Olsen is the general co-editor of the forthcoming 6-volume Cultural History of Youth (Bloomsbury) and the 4-volume Children, Childhood and Youth in the Long Nineteenth Century: A Global Primary Source Collection (Routledge). She co-edits the journal History of Education.

https://research.uta.fi/hex/people/

twitter: @Olsensid

${ }^{1}$ Stephanie Downes, Sally Holloway, and Sarah Randles, “A Feeling for Things, Past and Present," Feeling Things: Objects and Emotions through History (Oxford, 2018), p. 4. ${ }^{2}$ See Karen Vallgårda, Kristine Alexander and Stephanie Olsen, 'Emotions and the Global Politics of Childhood', in Childhood, Youth and Emotions in Modern History: National, Colonial and Global Perspectives, Stephanie Olsen, ed. (London, 2015), pp. 34 , for the initial exposition of these concepts.

${ }^{3}$ For a related discussion of Imperial belonging, see Kathryn Hunter, "National and Imperial Belonging in Wartime: The Tangled Knot of Australians and New Zealanders as British Subjects during the Great War," Australian Journal of Politics and History 63 no. 1 (2017), pp. 31-44.

${ }^{4}$ For more on whiteness and settler colonialism, see Marilyn Lake and Henry Reynolds, eds., Drawing the Global Colour Line: White Men's Countries and the International Challenge of Racial Equality (Cambridge, 2008).

${ }^{5}$ See for example, Andrew Donson, Youth in the Fatherless Land: War Pedagogy, Nationalism, and Authority in Germany, 1914-1918 (Cambridge, Mass., 2010); Bart Ziino, "They Seem to Understand All about the War": Australian Children and the First World War', Journal of the History of Childhood and Youth 11, no. 2 (2018), pp. 227 247; Charlotte Bennett, "Now the War Is Over, We Have Something Else to Worry Us": 
New Zealand Children's Responses to Crises, 1914-1918', Journal of the History of Childhood and Youth 7, no. 1 (2014), pp. 19-41; Kristine Alexander, 'An Honour and a Burden: Canadian Girls and the Great War', in A Sisterhood of Suffering and Service: Canadian and Newfoundland Girls and Women and the First World War, Sarah Glassford \& Amy Shaw, eds. (Vancouver, 2012), pp. 173-194; Manon Pignot, Allons enfants de la patrie. Génération Grande Guerre (Paris, 2012); Rosalie Triolo, Our Schools and the War (North Melbourne, 2012); Rosie Kennedy, The Children's War. Britain, 1914-1918 (Houndmills, 2014); Stephane Audoin-Rouzeau, La guerre des enfants 1914-1918 (Paris, 1993); Susan R. Fisher, Boys and Girls in No Man's Land: English-Canadian Children and the First World War (Toronto, 2011).

${ }^{6}$ Kate Darian-Smith and Carla Pascoe, eds. Children, Childhood, Cultural Heritage (Oxford, 2013), p. 2.

${ }^{7}$ Downes, Holloway, and Randles, "A Feeling for Things," p. 4.

${ }^{8}$ Ibid, 3-4. For a discussion of embodied emotions, see Rob Boddice, The History of Emotions (Manchester, 2018), pp. 120-124.

9 This would add an interesting case to Sara Ahmed's thesis about the "happiness duty," but affirms the overall point that the politics of happiness has a lot to do with the imperative to conform. See Sara Ahmed, The Promise of Happiness. Durham: Duke University Press, 2010.

10 "Which Path Will you Take" School Paper, January 1, 1914, Grades III and IV, pp. 5-6 and repeated in School Paper, November 1, 1927 edition, Grades III and IV, p. 156.

${ }^{11}$ Olsen, Stephanie. Juvenile Nation: Youth, Emotions and the Making of the Modern British Citizen, (London, 2014). 
${ }^{12}$ Carl Berger has famously argued that British imperialism was a form of settler nationalism in Canada. A similar case could be made for other settler colonies, yet in children's writings like these, and in the material culture produced by adults for children, it is also possible to tease out nascent nationalism, or even of strong community belonging that is distinct from imperial identities. See Carl Berger, The Sense of Power: Studies in the Ideas of Canadian Imperialism, 1867-1914, Second Edition, (Toronto: University of Toronto Press, 2013).

${ }^{13}$ Child Labour and Education: During the War and After. The Workers' Educational Association, (London, 1915), p. 2.

${ }^{14}$ Saleeby, C.W. Saving the Future: The War and the Coming Race, National Baby Week Council, (London, 1917), p. 6.

${ }^{15}$ Frederick J. Gould, History: The Supreme Subject in the Instruction of the Young. (London: Watts \& Co., 1918), p. 13.

${ }^{16}$ Yet even in the context of youth employment, this was primarily viewed as a "moral and not an economic issue." Final Report of the Departmental Committee on Juvenile Education in Relation to Employment after the War, (London, 1917) p. 22.

${ }^{17}$ W.J. Hindley, Rev. "The Moral Emphasis in Modern Education," Western School Journal (Winnipeg) X, 5 (1915), pp. 160-1, here 160.

${ }^{18}$ See, for example, City of Vancouver Archives, Vancouver School Board, Trustees Annual Report, 1914, S19 and Minutes of the Vancouver School Board Trustees, VSBS123, Box 56-A-2 (1914-15).

${ }^{19}$ Darian-Smith and Pascoe, eds. Children, Childhood, Cultural Heritage, p. 8.

${ }^{20}$ Frank Tate, "The Education Department, Victoria: Its Service in the War," Education Gazette and Teachers' Aid, (20 ${ }^{\text {th }}$ August, 1918) p. 249.

${ }^{21}$ Tate, "The Education Department," p. 250.

${ }^{22}$ School Paper, Nov. 1, 1916, Grades III and IV, pp.158-9.

${ }^{23}$ While certainly not the only nation to contest First-World-War conscription, Australia's two (narrowly) failed referenda illustrate the contentious issue of conscription policy there, and highlight the complicated debate about national service and duty. For more on this, Robin Archer, Joy Damousi, Murray Goot and Sean Scalmer, eds., The 
Conscription Conflict and the Great War (Melbourne: Monash University Publishing, 2016).

${ }^{24}$ John Clifford in F.J. Gould, Towards a World at Peace (Pages for Young Readers). (London: International Arbitration League, 1919), p. 4.

${ }^{25}$ Gould, Towards a World at Peace, p. 39.

${ }^{26}$ William J May, The Peacemaker. A Pageant Play in two Scenes. (Wellingborough: Perkins, 1922), p. 3.

${ }^{27}$ The organization responsible for this insert, the Sisters for International Peace, made official appeals to play down the militarist and pro-war tone of the School Paper. Special thanks to Kate Davison for pointing me to this material.

${ }^{28}$ Public Record Office, Victoria (PROV), Unit 100/1177 - "Patriotism in Peace and War" Essay Competition, (William Sidney Hornby, 13 years, 10 months, No. 1463).

${ }^{29}$ PROV, Unit 100/1177, (Thomas Stodard Clark, 13 years, 11 months).

${ }^{30}$ PROV, Unit 100/1177, (Connell Morgan, 12 years, 9 months).

${ }^{31}$ PROV, Unit 100/1177, (Bessie Shannon, Tallangatta).

32 PROV, Unit 100/1177, (Zita A Lord, 13 years, 6 months, Mitta Mitta).

${ }^{33}$ PROV, Unit 100/1177, (Percy Pepper, age 13, 2 months).

${ }^{34}$ PROV, Unit 100/1177, (Lord).

35 PROV, Unit 100/1177, (Eva Whitehand, 12 years, 5 months).

${ }^{36}$ PROV, Unit 100/1177, (Beth Cobham).

${ }^{37}$ PROV, Unit 100/1177, (Whitehand).

38 PROV, Unit 100/1177, (Shirley O’Leary, Tallangatta).

${ }^{39}$ PROV, Unit 100/1177, (Connell Morgan, 12 years, 9 months).

${ }^{40}$ Downes, Holloway and Randles, “A Feeling for Things,” p. 7. 